\title{
Early Intervention Program Through Bibliotherapy Approach For Reducing Fear In Orientation And Mobility Of Children With Visual Impairment
}

\author{
Euis Heryati $^{1 *}$, Endang Rochyadi ${ }^{2}$, Oom Sitti Homdijah ${ }^{3}$, Ehan $^{4}$ \\ ${ }^{1234}$ Department of Special Education, Universitas Pendidikan Indonesia, Indonesia \\ Email: euis_heryati@upi.edu
}

\section{INFORMASI ARTIKEL}

Terkirim 29-Juli-2021

Revisi 07-Agustus-2021

Diterima 10-Agustus-2021

Kata kunci:

bibliotherapy, fear,

orientation and mobility,

children with visual

impairment

\begin{abstract}
ABSTRAK
Orientation and mobility skills are special skills that must be mastered by children with visual impairment, thus an orientation and mobility intervention program is important to develop. Fear or anxiety in children with visual impairment related to orientation and mobility can be caused by fear from within the children or from the environment. Personality, motivation, psychosocial factor, and family and community attitudes all contribute to one's reaction to mobility activities independently. This research aims to reduce the fear of children with visual impairment in performing orientation and mobility activities by implementing an intervention program through bibliotherapy technique. This research is a case study research with a qualitative approach. Bibliotherapy was carried out on two young children with visual impairment. The results of the program implementation show that children's fear or anxiety could be reduced in both cases in this research as seen by autonomous moves of the two children from the mother and caregiver and began to learn to trace the walls of the room.
\end{abstract}

\section{Introduction}

Visual impairments are one of the causes of childhood disabilities. For children with visual impairments, the ability to move (mobility) independently and confidently will greatly affect their learning experience. Visual experience is very important to help children in their learning to integrate sensory information. Early intervention in children with visual impairment is very important, and the handling of sensory input disorder must begin at the earliest possible regarding the regulation of positive emotions that can increase children's motivation in their relation with the environment.

Children with visual impairment experience unfavorable development because they must rely on senses other than their vision. The lack of visual stimulation negatively impacts various areas of development (physical, cognitive and language) in children (Tuncer, 2004 in Arslantekin, 2017). They usually experience delays in concept development (Budd, 1998, in Arslantekin, 2017). Concept development is an important tool for overall development in both alert children and children with visual impairment, in addition to efficient teaching and learning (Olayi \& Ewa, 2014, in Arslantekin, 2017). For children with visual impairment, they need to learn how to integrate their senses by touching, smelling, tasting, and using their remaining vision. The initial concept development underlies their subsequent development.

Early intervention programs for children with visual impairment generally focus more on orientation and mobility (O\&M), playing skills, and everyday life skills (Goergen, 1997; Lanners, 
Piccioni, Fea, \& Goergen, 1997). Orientation and mobility are one area of skills that distinguish visual impairment from other disabilities. Also, these skills are the most fundamental to be supported and developed for children with visual impairment (Brambring, 2006; Celeste, 2002). This is an important area of development because of its effect on other aspects of development. Therefore, an early intervention program for this group of children needs to focus on developing orientation and mobility skills.

Visual impairment or blindness can be the initial trigger for the emergence of fear in children and this group of children is at high risk for falling due to impaired balance as a result of blindness. In addition, they also have difficulty identifying environmental threats and are limited in their mobility.

It has long been known that many children with visual impairment feel scared of the idea traveling independently. That can be caused by fear from within a child or from the environment. Personality, motivation, psychosocial factor, and family and community attitudes all contribute to one's reaction to mobility activities independently; such as concern about self-injury or being lost in an unknown or changing environment. Orientation and mobility activities often focus mainly on training and the components of independent walking skill, with one's psychological status playing a lower role. Children with visual impairments may not be ready to exercise functional skills if they are still too scared (Baskett, L. 2005).

It is essential that one's fears are recognized and that recognized signs of individual stress can be caused by fear. Only then can techniques be implemented to help manage these fears. Traveling independently or even thinking about traveling independently is an example of a stressor. Stress and fear can be motivating factors to help achieve goals, but too much stress can interfere with our ability to think clearly or to achieve goals (Healthy Lifestyle Unit, 1999).

The signs of fear and stress can be placed in different groupings which include: psychological depression, anxiety, excessive worry; thought disorder - poor concentration, procrastination, irrational fear, self-awareness; behavior change of withdrawing self, phobic reaction, poor treatment, hesitation; withdraw socially from various activities and friends; and increased physical blood pressure, disturbed sleep, palpitation, and excessive sweating (Healthy Lifestyle Unit, 1999).

General fear or anxiety in relation to orientation and mobility is related to one or more of the five main areas, which include: interpersonal anxiety that is activated in situations involving interaction with others, physical danger anxiety where the person faces physical injury problems, ambiguous anxiety which is activated by a threatening situation where the person does not know what will happen next, social evaluation anxiety that is activated by a situation involving threats to one's self-esteem as a result of being evaluated by others, and daily routine anxiety that is activated by the situation at hand in everyday situations (R.L. Welsh, 1999).

Orientation and mobility training requires a child's mental or psychological readiness, so it is important to eliminate the anxiety or fear of each child who will carry out orientation and mobility activities beforehand. The use of book as a therapeutic medium is called bibliotherapy. Bibliotherapy is psychotherapy support through reading material to help someone who is experiencing personal problem. This therapeutic method is highly recommended especially for patient who has difficulty expressing his problem verbally (Suparyo, 2010 in Darmawan, W., et al, 2012). 
Bibliotherapy is also known by other names such as bibliocounseling, biblioeducation, or biliopsycology. Webster (1961) found that bibliotherapy can reduce fear in first grade students, in contrast to the research of Dixon (1974) and Link (1977) who did not find the effectiveness of bibliotherapy in reducing fear and anxiety in individuals they researched on. However, recent research conducted by Chambers (1985), Dixon (1988), Mackenzie (1989), Tindall (1986), Tremewan and Strongman (1991) and Tucker (1981) concluded that fiction provides effective meaning for a child in overcoming his fear (Herlina, 2013).

In 1980, Watson explained the objectives of bibliotherapy include (1) teaching positive and constructive thinking, (2) encouraging freedom of expression about the problem, (3) helping client analyze their attitude and behavior, (4) finding alternative solution, (5) encouraging client to find ways of dealing things that are not in conflict with the community, and (6) allowing client to see the similarity of their problems with others (Henderson, D.A \& Thompson. C.L., 2016).

\section{Method}

This research aims to explore the implementation of an intervention program through a bibliotherapy approach to reduce fear in orientation and mobility in two young children with visual impairment. The method used in this research is a case study with a qualitative approach. Data collection techniques were done through interviews and observations. Participant: the participants in this research involved two children with visual impairment ( $\mathrm{Vn}$ and Sy), two interventionists, and the parents of the two children.

\section{Result And Discussion}

\section{Case Study 1}

Vn was a child aged 4.5 years who had visual impairment of blind condition since birth due to ROP abnormality (retinopathy of prematurity). The orientation ability was still very limited and independent mobility was still not brave. Vn still asked to be carried or if he was walking, he held on tight to his mother, often looked scared when he let go of his hand. Walking position and way were upright normal position, even though it still seemed stiff when he walked. His mother was very careful when inviting Vn to walk down the room. After several visits to the intervention site, Vn still did not want to be held or invited to walk by interventionists, and still always asked to sit or hold his mother.

\section{Case Study 2}

Sy was a 6-year-old child who was visually impaired with a condition of blindness from birth due to ROP abnormalities (retinopathy of prematurity). The orientation ability was still very limited and independent mobility was still not brave. Walking position and way were upright normal position, even though it still seemed stiff when he walked. Sy preferred sitting while holding an object in the form of a cloth hanger. This object must always be held when walking while holding tight to the caregiver. Sy was still scared or did not dare to walk alone through the room. As the caregiver said, if Sy was taught to walk alone, he would hold a cloth hanger and hugged me. Else, he would scream." 


\section{Bibliotherapy Implementation}

Orientation and mobility (O\&M) skills in the above two cases of children with visual impairment were still very limited, and mobility training was still unable to conduct because of such fear or anxiety in both children. One of the efforts made to reduce fear in the two children was child counseling program by using the bibliotherapy approach. Bibliotherapy or also known as bibliocounseling is a form of psychotherapy support by utilizing book as its medium. The purpose of applying bibliotherapy in this research was to reduce the fear or anxiety that existed in those children when orientation and mobility intervention would be carried out.

\section{Table of Intervention Program with Bibliotherapy Approach in Young Children with Visual} Impairment

\begin{tabular}{|c|c|c|}
\hline Child's Objective Condition & Procedures & Objectives \\
\hline $\begin{array}{l}\text { Case 1: } \\
\text { Vn was very limited in his } \\
\text { independent mobility, he } \\
\text { often asked to be held tight } \\
\text { to his mother, he often } \\
\text { looked scared when he let } \\
\text { go of his hand. When the } \\
\text { intervention underwent, he } \\
\text { still asked to sit on his } \\
\text { mother's lap. }\end{array}$ & $\begin{array}{l}\text { This bibliotherapy technique uses } \\
\text { the selected books media as } \\
\text { needed. The selected books are } \\
\text { books about stories of daily } \\
\text { activities that are usually carried } \\
\text { out by children. } \\
\text { Procedure: } \\
\text { - interventionist opens the } \\
\text { activity by sitting in a circle } \\
\text { with the child and }\end{array}$ & $\begin{array}{l}\text { - } \text { reduce fear or anxiety } \\
\text { in orientation and } \\
\text { mobility } \\
\text { - } \text { remove the child's } \\
\text { dependence on his } \\
\text { mother when O\&M } \\
\text { interventions are } \\
\text { carried out }\end{array}$ \\
\hline $\begin{array}{l}\text { Case } 2 \text { : } \\
\text { Sy was still very limited in } \\
\text { his orientation and mobility, } \\
\text { he was very afraid of } \\
\text { learning to walk alone. He } \\
\text { preferred sitting while } \\
\text { holding onto an object in the } \\
\text { form of a cloth hanger. This } \\
\text { object must always be held } \\
\text { when he walked while he } \\
\text { held on tight to the } \\
\text { caregiver. Sy's caregiver } \\
\text { must always be close during } \\
\text { the intervention. }\end{array}$ & $\begin{array}{l}\text { parents/caregivers, reading } \\
\text { prayers, then singing together } \\
\text { - } \text { interventionist starts reading } \\
\text { the story book to the end } \\
\text { interventionist reflects and } \\
\text { discusses the contents of the } \\
\text { story with the children } \\
\text { interventionist asks about the } \\
\text { children's feelings after } \\
\text { hearing a story book. } \\
\text { This activity is conducted one or } \\
\text { two sessions (one story book } \\
\text { session) for each meeting. }\end{array}$ & 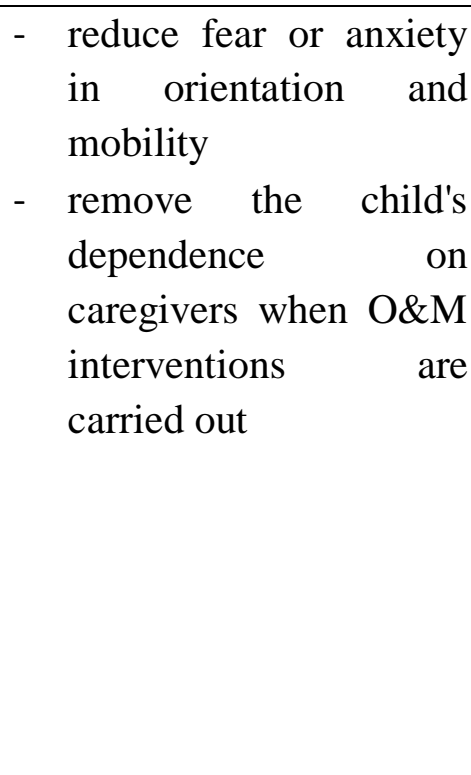 \\
\hline
\end{tabular}

After the program had been for three meetings, the two children ( $\mathrm{Vn}$ and Sy) could be separated from the mother or caregiver. At the fourth meeting, the two interventionists could hold and invited Vn and Sy to stand up and walk around the room. Although both were still holding on to the 
interventionists, Vn's mother and Sy's caregiver had been able to leave them in the intervention room. The implementation of bibliotherapy technique could reduce fear in the two cases in this research as seen by the autonomous move of the two children from the mother and caregiver and began to dare to learn walking along the walls of the room. This is in line with research conducted by Chambers (1985), Dixon (1988), Mackenzie (1989), Tindall (1986), Tremewan and Strongman (1991) and Tucker (1981) who concluded that fiction provides effective meaning for children in overcoming their fears (Herlina, 2013).

\section{Conclusion}

Visual impairment or blindness can be a trigger for the emergence of fear in children. They have difficulty in identifying environmental threats and are limited in mobility. Fear of mobility can be triggered by fear from within the child or from the environment. The implementation of bibliotherapy technique can reduce fear in children with visual impairment so that they are ready to exercise functional orientation and mobility skills. Bibliotherapy can help motivate children to understand their condition that has visual impairment so that they have the courage to face the difficulties experienced by this impairment.

\section{Refferences}

Anthony, T. L., Bleier, H. F., Fazzi, D., Kish, D., \& Pogrund, R. (2002). Mobility focus: developing early skills for orientation and mobility. In R. Pogrund \& D. Fazzi (Eds.), Early focus: Working with children who are blind or visually impaired and their families. New York: American Foundation for the Blind.

Arslantekin, B.A (2017). Evaluation of the Level of Students with Visual Impairments in Turkey in Terms of the Concepts of Mobility Prerequisites (Body Plane/Traffic). Eurasian Journal of Educational Research 67 (2017) 71-85. DOI: http://dx.doi.org/10.14689/ejer.2017.67.5

Baskett, L. (2005). Fear of orientation and mobility. International Congress Series 1282 (2005) 469473 Elsevier B.V. Doi:10.1016/j.ics.2005.05.104

Brambring, M. (2006). Divergent developmental of gross motor skills in children who are blind or sighted. Journal of Visual Impairment \& Blindness, 100(10), 620-634.

Celeste, M. (2002). A survey of motor development for infants and young children with visual impairments. Journal of Visual Impairment \& Blindness, 96(3), 169-174.

Darmawan, W., dkk. (2012). Penerapan Biblioterapi di Rumah Sakit Dr. Cipto Mangunkusumo. eJournal Mahasiswa Universitas Padjajaran Vol. 1. No. 1 (2012)

E. Fazzia, S.G. Signorinia., et al . (2005) Early intervention in visually impaired children. International Congress Series 1282 (2005) 117-121. 0531-5131/ D 2005 Elsevier B.V

Goergen, E. (1997). Italy: Early intervention with visually impaired children with additional handicaps. Journal of Visual Impairment and Blindness, 91(1), 89-92. 
Herlina. (2013). Bibliotherapy: Mengatasi Masalah Anak dan Remaja melalui Buku. Bandung: Pustaka Cendekia Utama

Henderson, D.A., Thompson. C.L. (2016). Counseling Children, Ninth Edition. USA: Cengage Learning.

Healthy Lifestyle Unit. (1999). Learn to Unwind, Relaxation and Stress Management Techniques. Department of Health, NSW, Australia.

R.L. Welsh. (1999). The psychosocial dimensions of orientation and mobility., in: R.L. Welsh, B.B. Blasch (Eds.). Foundations of Orientation and Mobility, American Foundation for the Blind, New York, 1999, pp. 200- 227.

Scott, B. (2008). Early Intervention Orientation and Mobility: A Western Australian Perspective . International Journal of Orientation \& Mobility • Volume 1, Number 1, 2008

Tröster, H., \& Brambring, M. (1993). Early motor development in blind infants. Journal of Applied Developmental Psychology, 14, 83-106. 